\title{
METODA KONTRASTYWNA I KRYTERIA TEKSTUALNOŚCI W PRZEKLADZIE TEKSTÓW PRAWNICZYCH
}

\author{
PAWEL BIELAWSKI \\ Universität Leipzig \\ Institut für Angewandte Linguistik und Translatologie \\ bielawski.pp@gmail.com
}

\begin{abstract}
Abstrakt: Niniejszy tekst dotyczy translacji tekstów prawniczych. Autor definiuje pojęcie tekstów tego rodzaju i zwraca uwagę na wynikającą $\mathrm{z}$ ich statusu szczególną odpowiedzialność związaną z ich przekładem.

$\mathrm{W}$ tekście podkreślony jest ścisły związek prawa z krajem, w którym ono obowiązuje i wynikająca z tego unikalność konceptualno-terminologiczna. Na tym tle przedstawione są kwestie dotyczące metod kontrastywnych: komparatystyki prawniczej i terminologicznej. Autor wskazuje cechy obu komparatystyk i podkreśla istniejące między nimi różnice i podobieństwa. Założenia obu metod porównawczych są odniesione do przekładu tekstów prawniczych. W ostatnim kroku autor podkreśla rolę siedmiu kryteriów tekstualności w procesie przekładu.

Celem niniejszego tekstu jest wskazanie na istotę analizy porównawczej oraz aspektów tekstualności w przekładzie tekstów prawniczych. Autor zwraca uwagę na te aspekty przekładu, które umożliwiają sporządzenie translatu równoważnego z tekstem źródłowym pod względem funkcjonalnym.
\end{abstract}


Paweł Bielawski: Metoda kontrastywna i kryteria tekstualności...

Słowa klucze: przekład prawniczy, analiza kontrastywna, komunikacja specjalistyczna, konwencje gatunkowe, tekstualność

\title{
CONTRASTIVE APPROACH AND TEXTUALITY IN LEGAL TRANSLATION
}

\begin{abstract}
This paper focuses on legal translation. First, the author defines legal texts and points to particular responsibility related with legal translation resulting from the status of these texts.

Turning to the aspects of translation, the author underlines the boundness of each legal system to the country it is in force. At the same time, he points to the conceptual and terminological uniqueness resulting from this boundness. Against this backdrop, the premisses of, both, the comparative law and comparative terminology are presented. With regard to legal translation the similarities and differences existing between both comparative approaches are stated. In the final step, the author points to the importance of seven standards of textuality in legal translation.

The purpose of the present paper is to emphasize the importance of the comparative approach and of the textuality for legal translation. The Author stresses here these aspects of translation which allow the target text to become a functional equivalent to the source text.
\end{abstract}

Key words: legal translation, contrastive approach, communication for special purposes, textual convention, textuality

\section{KONTRASTIVES HERANGEHEN UND TEXTUALITÄT IN DER ÜBERSETZUNG JURISTISCHER TEXTE}

\begin{abstract}
In dem vorliegenden Text wird der Übersetzungsprozess juristischer Texte analysiert. Zunächst definiert der Verfasser juristische Texte und hebt hervor eine besondere Verantwortung, die mit dem Übersetzen dieser Texte einhergeht.

Im ersten Schritt wird die Verbindung zwischen Recht und Staat unterstrichen und darauf hingewiesen, dass dies begriffliche und mithin terminologische Unterschiede bewirkt. Vor diesem Hintergrund werden kontrastive Methoden in den Mittelpunkt gestellt: die Rechtsvergleichung und der terminologische Vergleich. Voraussetzungen beider Herangehensweisen werden erörtert in bezug auf Übersetzung juristischer Texte. Im letzten Schritt betont wird die Rolle von sieben Kriterien der Textualität im Übersetzungsprozess.

Das Ziel des vorliegenden Textes ist es, die Bedeutung kontrastiver Methoden und der Textualitätskriterien für Übersetzung juristischer Texte hervorzuheben.
\end{abstract}


In Fokus geraten hier diejenigen Übersetzungsaspekte, die es ermöglichen, einen mit dem Ausgangstext funktional äquivalenten Zieltext zu erstellen.

Schlagwörter: juristische Übersetzung, kontrastive Methoden, Fachkommunikation, Textsortenkonventionen, Textualität

\section{Wstęp}

Przekład tekstów prawniczych jest zadaniem szczególnym i różni się od przekładu tekstów specjalistycznych innych dziedzin. Wynika to moim zdaniem z dwóch czynników: Pierwszym jest ścisłe powiązanie systemu prawnego z krajem, w którym dane prawo obowiązuje. Owa ścisła więź i zależność znajduje swoje odzwierciedlenie w unikalności systemów konceptualnych, a co za tym idzie również systemów terminologicznych prawa.

Drugi z czynników dotyczy aspektu aplikatywnego. Zastosowanie tekstów prawniczych w praktyce, oryginalnych w kraju języka źródłowego i translatów (uwierzytelnionych) w kraju języka docelowego, wiąże się z określonymi skutkami prawnymi. Wykorzystanie thumaczenia w kraju języka docelowego ma miejsce np. w sytuacji wykonania wyroku zagranicznego. Od poprawności wykonania thumaczenia może zależeć zgoda na wykonanie takiego orzeczenia - dotyczy to $\mathrm{np}$. wydanych za granicą orzeczeń w sprawach karnych, które pod względem formalnym muszą być zgodne z prawem kraju, w którym mają one zostać wykonane (w Polsce stanowi o tym Art. 114a kk).

Ów drugi czynnik przesądza nie tylko o szczególności przekładu tekstów prawniczych, lecz również o szczególnej odpowiedzialności tłumacza wykonującego uwierzytelnione tłumaczenia dokumentów, zwłaszcza dla wymiaru sprawiedliwości (sądy) oraz organów ścigania (prokuratura, policja).

Pierwszy z nich natomiast determinuje podejście metodologiczne w procesie przekładu. Wśród przekładoznawców i prawoznawców panuje zgoda, iż jedynie metoda porównawcza (komparatystyka, metoda kontrastywna) pozwala stwierdzić różnice oraz podobieństwa pomiędzy porządkami prawnymi oraz ich systemami konceptualnymi (Sandrini 1998a: 865; 1998b: 153; de Groot 1999: 11; 1985: 14-15). 
Można jednak zauważyć, że istnieją przynajmniej trzy podejścia do tej metody w kontekście przekładu: prawnicze, terminologiczne i translatoryczne.

Komparatystyka prawnicza jest metodą prawoznawczą i różni się w pewnym stopniu od podejścia kontrastywnego, stosowanego w terminologii oraz w przekładzie. W samej komparatystyce prawniczej można według mnie wyróżnić dodatkowo dwa podejścia: Prawnicy teoretycy porównują systemy prawne, tzn. szukają różnic i podobieństw między regulacjami przynajmniej dwóch systemów prawnych; prawnicy praktykujący z kolei porównują systemy prawne w kontekście określonych przypadków, które podlegają rozstrzygnięciu w oparciu o prawo obcego kraju. Praktykujący prawnik szuka zatem odpowiedzi na pytanie, w jaki sposób dany problem jest rozwiązywany w obcym systemie prawnym (Mincke w: Arntz 1999: 187). ${ }^{1}$ Zadaniem prawnika teoretyka jest natomiast ustalenie ogólnej relacji pomiędzy porównywanymi systemami prawnymi.

Metoda porównawcza stosowana przez terminologów opiera się na analizie pojęć terminów w kontekście systemu terminologicznego danej dziedziny albo poddziedziny i zestawieniu ich z pojęciami terminów systemu terminologicznego występującego w innym kraju. Celem takiego porównania jest ustalenie różnic i podobieństw pomiędzy konceptami, których środki wyrazu należą do różnych systemów językowych (Arntz 1999: 187-188).

Podejście kontrastywne w przekładzie tekstów prawniczych zawiera w sobie w moim rozumieniu elementy komparatystyki prawniczej oraz terminologicznej i poszerzone jest o aspekty lingwistyczne, takie jak kolokacje czy konwencje gatunkowe. Podobnie jak prawoznawcę thumacza interesują różnice i podobieństwa, te strukturalne i normatywne, między systemem prawnym kraju języka źródłowego i docelowego. Podobnie jak terminologa tłumacza interesuje zakres tłumaczonych konceptów, $\mathrm{z}$ tą jednak różnicą, że tłumacz nie porównuje terminów w kontekście całego systemu terminologicznego, lecz w kontekście zdarzenia, którego dotyczy thumaczony tekst. Decydującym kryterium dla thumacza nie jest też "całkowita ekwiwalencja" terminów, ta istnieje bowiem jedynie w przypadku krajów wielojęzycznych z jednym systemem prawnym (np.

\footnotetext{
1Uwzględnienie obcego prawa w sprawach sądowych dotyczy w szczególności spraw cywilnych. W Polsce przewiduje i reguluje to kodeks postępowania cywilnego (Art. 1143 $\mathrm{kpc}$ ). W oparciu o prawo zagraniczne rozstrzyga się w Polsce np. o zdolności do czynności prawnych osoby fizycznej, która nie posiada polskiego obywatelstwa - przewiduje to ustanowione w Polsce Prawo prywatne międzynarodowe (ppm) (Art. 11 ust. 1 ppm).

92
} 
Szwajcaria albo Finlandia), lecz zachodząca między nimi zgodność funkcjonalna - w przekładzie wystarczy zatem, że koncept w obu krajach 'rozwiązuje ten sam problem' (Sandrini 1996: 244).

W niniejszym artykule przedstawione są teorie i różne podejścia do metody kontrastywnej w odniesieniu do przekładu tekstów prawniczych. Teksty prawnicze, to w moim rozumieniu dokumenty, które sporządzane są przez prawników w ramach wykonywanego zawodu (adwokata, prokuratora czy sędziego). Nie są to zatem wszystkie teksty stanowiące przedmiot prawa, które można nazwać tekstami prawa. Do tekstów prawniczych nie zaliczam takich klas tekstów prawa jak: dokumenty urzędu stanu cywilnego (np. akt urodzenia, akt małżeństwa), dokumenty księgowo-podatkowe (zeznanie podatkowe, sprawozdanie finansowe), dokumenty handlowe (np. umowa cywilna, umowa najmu), dokumenty policyjne (np. protokół przyjęcia ustnego zawiadomienia o przestępstwie), dokumenty z zakresu prawa pracy (np. świadectwo pracy, umowa o pracę) czy akty notarialne (np. testament, pełnomocnictwo $)^{2}$.

Tekst niniejszy odnosi się przede wszystkim do przekładu tekstów prawa stosowanego, czyli takich, które związane są ze stosowaniem prawa (np. wyrok, akt oskarżenia, wniosek o ukaranie). Wyrażane tu poglądów odnoszą się również do tekstów teoretycznych, tj. takich, które traktują o prawie (np. podręcznik dla studentów prawa, artykuł naukowy, komentarz do ustawy), oraz do tekstów normatywnych (np. ustawa). Te ostatnie nie są wprawdzie powszechnie thumaczone w całości, jednak dosłowne przytaczanie ich fragmentów nierzadko ma miejsce w przypadku sporządzania wyroków czy aktów oskarżenia. Warto w tym kontekście zauważyć, że chociaż ustawodawca jest niekwestionowanym autorem idei i treści tego gatunku tekstu, to treść ta jest wyrażana w oparciu o system konceptualny języka prawniczego przez prawników właśnie. Różnica pomiędzy tekstami normatywnymi oraz innymi tekstami prawniczymi dotyczy z prawniczego punktu widzenia ich rangi, z lingwistycznego - oprócz zasadniczych cech gatunkowych - poziomu abstrakcji, który w przypadku tekstów normatywnych, jest z racji ich ogólności dużo wyższy (Otto 1981: 51).

\footnotetext{
2 Notariuszem może wprawdzie zostać powołana tylko osoba, która ukończyła wyższe studia prawnicze, o czym stanowi polskie prawo o notariacie (Art. 11 pkt. 3), jednak dokumenty notarialne mają według mnie charakter dokumentów handlowych oraz aktów urzędu stanu cywilnego.
} 
Celem niniejszego tekstu jest wskazanie na istotę analizy porównawczej w przekładzie tekstów prawniczych. W tym celu omówione zostaną założenia metody komparatystyki prawniczej oraz terminologicznej, a także istota konwencji gatunkowych. W ten sposób chcę zwrócić uwagę na te aspekty przekładu tekstów prawniczych, które w kraju języka docelowego pozwalają translatowi spełniać taką samą funkcję, jaką tekst oryginalny pełni w kraju języka źródłowego.

\section{Związek prawa z państwem i jego kulturą}

De Groot (1991), holenderski prawoznawca specjalizujący się w komparatystyce prawniczej, zauważył niegdyś, iż prawo jest ściśle związane z systemem oraz kulturą kraju, w którym obowiązuje. W tym kontekście stwierdził on konsekwentnie, że nie można wobec tego mówić o niderlandzkim języku prawa uniwersalnym dla wszystkich obszarów niderlandzkojęzycznych. Każde terytorium, na którym język ten ma status języka urzędowego (Królestwo Niderlandów, Surinam i Belgia), ma bowiem odrębny system prawny z własnym systemem konceptualnym; dodatkowo w samym Królestwie Niderlandów obowiązują trzy porządki prawne: europejskiej części Królestwa (Holandii), Antyli Holenderskich i wyspy Aruba (de Groot 1991: 283-284) ${ }^{3}$.

Teza kulturowego uwarunkowania języka prawa ${ }^{4}$ postawiona przez de Groota w kontekście przekładu ma zastosowanie do wszystkich języków świata: Nie można zatem mówić o angielskim języku prawa uniwersalnym we wszystkich krajach angielskojęzycznych czy francuskim uniwersalnym na wszystkich obszarach francuskojęzycznych. W odniesieniu do krajów niemieckojęzycznych analogii dokonał m.in. Sandrini (1998a, 1999a). Ten austriacki językoznawca zauważył tym kontekście, że translacja nie polega na tłumaczeniu z języka wyjściowego na język

3 Od października 2010, kiedy Antyle Holenderskie zostały rozwiązane, a ich wyspy Sint Maarten i Curaçao uzyskały status autonomicznych krajów wchodzących w skład Królestwa Niderlandów, należy mówić nie o trzech, lecz o czterech porządkach prawnych.

4 Olpińska proponuje sformułowanie ,język specjalistyczny prawa”, w celu uniknięcia dokonanego przez Wróblewskiego (1948) podziału na język prawny, występujący w tekstach normatywnych takich jak konstytucja, kodeks, ustawa i prawniczy, czyli taki, którego autorem jest prawnik lub osoba reprezentująca wymiar sprawiedliwości (pozew, wyrok, protokół przesłuchania sądowego) (Olpińska 2009:79).

94 
docelowy, lecz jest przekładem z języka pewnego porządku prawnego na język innego porządku prawnego - najczęściej są to odmienne porządki prawne, a czasem, jak w przypadku Szwajcarii, ten sam (Sandrini 1998a: 865; 1999a: 16).

Pogląd de Groota i Sandriniego dotyczący uwarunkowania prawa przez czynniki historyczne, polityczne i społeczne - jednym słowem czynniki te można określić kulturowymi - jest zbieżny z przekonaniem innych teoretyków prawa oraz antropologów, według których prawo stanowi indywidualny sposób organizowania życia społecznego i rozwiązywania problemów przez daną społeczność (Raz 2009: 98-99; Grossi 2010: x-xi; Mayer 1933: 26-28). ${ }^{5}$

Fakt kulturowego uwarunkowania prawa powoduje, że terminy z zakresu prawa nie są uniwersalne, tzn. nie wszystkie występują w każdym kraju, a te, które występują w kilku krajach, najczęściej reprezentują odmienne pojęcia i niosą ze sobą odmienne skutki prawne. Kulturowe uwarunkowanie prawa jest wobec tego przyczyną największych trudności, na jakie natrafiają tłumacze - trudności dotyczące przekładu pojęć prawnych. W życiu codziennym różnice istniejące pomiędzy systemami prawnymi są również pewnego rodzaju przeszkodą dla współpracy międzynarodowej w wymiarze politycznym, gospodarczym, handlowym i prywatnym. I to właśnie utrudnienia w życiu codziennym spowodowane różnicami pomiędzy systemami prawnymi stały się bodźcem do poszukiwań rozwiązań pozwalających trudności te pokonać.

\section{Komparatystyka prawnicza}

Idea komparatystyki prawniczej zrodziła się na początku XX wieku i postrzegana wtedy była jako wstępne stadium unifikacji prawa $\mathrm{w}$ Europie w celu usprawnienia współpracy międzynarodowej (Zweigert i Kötz 1996: 2). Okres dwóch wojen światowych nie sprzyjał jednak realizacji tego zamiaru, ponieważ współpraca międzynarodowa miała wów-

\footnotetext{
$5 \mathrm{~W}$ tym kontekście należy jednak wziąć pod uwagę poglądy o wzajemnym uwarunkowaniu prawa i kultury. Mezey uważa, że pewne regulacje prawne są w stanie wpływać na kształt kultury (2001: 46-47). Podobne stanowisko reprezentuje również Bourdieu (1987: 838-839, 846).
} 
czas wymiar, w którym aspekty prawne nie były istotne. Dziś można zauważyć, że zamiar sprzed ponad stu lat został w pewnym stopniu zrealizowany w niektórych dziedzinach prawa, czego przykładem jest Prawo Unii Europejskiej.

Wagę komparatystyki prawniczej uzasadniano kiedyś i uzasadnia się dziś potrzebą sprostania wymaganiom, stawianym przez intensyfikujące się kontakty międzynarodowe (Zweigert i Kötz 1996: 57). Niezaprzeczalny jest bowiem fakt, iż znajomość obcego prawa usprawnia międzynarodowe kontakty handlowe.

Zweigert i Kötz rozróżniają porównanie na poziomie makro oraz mikro. Komparatystyka na poziomie makro polega na porównywaniu całego systemu, albo pewnych gałęzi prawa przynajmniej dwóch systemów prawnych - jest to porównanie ogólne i całościowe, bez odniesienia do konkretnego przypadku życia codziennego. Przykładem jest np. porównanie prawa konstytucyjnego, karnego lub spadkowego przynajmniej dwóch systemów prawnych (K. Zweigert i H. Kötz 1996: 4). Komparatystyka na poziomie mikro dotyczy natomiast porównywania aspektów prawnych w odniesieniu do określonych zagadnień czy przypadków życia codziennego i służy ich rozwiązywaniu. Postulowanym przez wspomnianych autorów kryterium komparatystyki prawniczej jest funkcjonalność - chodzi przy tym o poszukiwanie regulacji pełniących taką samą funkcję, czyli rozwiązujących takie same problemy (Zweigert i Kötz 1996: 4-5, 33).

Metoda komparatystyki prawniczej powinna według mnie znaleźć zastosowanie w pracy tłumacza ze względu na różnice występujące między systemami prawnymi oraz przez zasadniczy brak możliwości wykonania skutecznego przekładu za pomocą słowników prawniczych w słownikach prawie nigdy nie jest uwzględniona przynależność terminu do systemu prawnego, często brak w nich również kontekstu użycia. Metoda makro-porównania jest według mnie właściwa dla przekładu ogólnych tekstów normatywnych, takich jak konstytucja czy ustawy (kodeksy). Mikro-porównanie natomiast może znaleźć zastosowanie w przekładzie dokumentów prawniczych, dotyczących konkretnych sytuacji życiowych i przypadków prawnych - chodzi tu zatem o takie teksty, które mają konkretnych odbiorców, i których autorem jest przede wszystkim prawnik. 
Zweigert i Kötz (1996) zwracają uwagę na ideę kręgów prawnych, która dotyczy klasyfikacji systemów prawnych ze względu na istniejące między nimi podobieństwa. Kwestia ta jest według mnie dla tłumacza o tyle ważna, że świadomość przynależności dwóch systemów prawnych do tego samego kręgu sygnalizuje możliwość występowania zbieżności pewnych zagadnień, regulacji czy konceptualizacji. Oznacza to, że w przypadku, kiedy system prawny tekstu źródłowego i docelowego należą do tego samego kręgu, tłumacz może spodziewać się mniejszych różnic regulatywnych i terminologicznych aniżeli w przypadku, gdy systemy prawne należą do różnych kręgów. Dotyczy to jednak tylko prawa prywatnego (cywilnego), ponieważ, na co uwagę zwracają autorzy, teoria kręgów prawnych uwzględnia tylko tą dziedzinę prawa (Zweigert i Kötz 1996: 64). Podobieństwa pomiędzy systemami prawnymi na gruncie np. prawa konstytucyjnego czy karnego nie są zatem przez teorię kręgów prawnych przesądzone.

\section{Zastosowanie komparatystyki prawniczej przekładzie}

$\mathrm{Na}$ istotę zastosowania elementów komparatystyki prawniczej w przekładzie tekstów prawniczych zwrócił uwagę de Groot (1985, 1999). Analizując pojęcia z zakresu niemieckiego i niderlandzkiego prawa cywilnego, stwierdził on, że można je poprawnie przetłumaczyć pod warunkiem, iż ustali się istniejące między nimi różnice i podobieństwa dotyczące funkcji, jaką pełnią. Metodą, która według niego pozwala takie różnice i podobieństwa stwierdzić, umożliwiając dzięki temu sporządzenie translatu zbliżonego do oryginału pod względem funkcjonalnym, jest komparatystyka prawnicza, czyli analiza porównawcza systemów prawnych (de Groot 1999: 11, 1985: 14-15).

W kontekście komparatystyki prawniczej de Groot koncentruje swą uwagę na problemy związane z ekwiwalencją, która, co sam podkreśla, w zakresie terminologii prawniczej, w zasadzie nie istnieje. Problemy te wynikają z uwarunkowania prawa przez realia społeczno-polityczne kraju, w którym dane prawo obowiązuje (de Groot 1990: 124; 1999: 20). W tym kontekście holenderski prawoznawca zwraca uwagę na konieczność dodatkowych operacji ze strony tłumacza, dzięki którym różnice konceptualne można zniwelować i osiągnąć translat funkcjonalnie równowartościowy, tzn. taki, który w kraju języka docelowego wywoływał 
będzie takie skutki, jakie dokument oryginalny wywołuje w kraju języka źródłowego. W przypadku kiedy nie można ustalić akceptowalnego ekwiwalentu w języku docelowym de Groot proponuje trzy rozwiązania: Pierwszym jest użycie w tekście docelowym wyrażenia obcego z ewentualnym wyjaśnieniem w postaci thumaczenia dosłownego albo wytłumaczenia w przypisie. Drugą możliwością jest thumaczenie opisowe. Trzecim zabiegiem jest użycie neologizmu $\mathrm{z}$ ewentualnym wyjaśnieniem w przypisie (de Groot 1999: 27).

Z zaproponowanych trzech sposobów mających wyeliminować różnice konceptualne, można moim zdaniem zaakceptować tylko drugą możliwość. Sposoby pierwszy i trzeci są według mnie w sposób jawny sprzeczne z zadaniem stawianym tłumaczowi, jakim jest umożliwienie odbiorcy zrozumienie komunikatu tekstu źródłowego za pomocą translatu.

Wobec powyższego i w odniesieniu do kulturowego uwarunkowanie prawa należy moim zdaniem wyciągnąć dwa wnioski: Po pierwsze, tłumacząc teksty prawnicze, należy wziąć pod uwagę nie tyle język docelowy, co system prawny, na który się tłumaczy. W tłumaczeniu na język niderlandzki dokumentu, który ma znaleźć zastosowanie w Holandii, znajdą się odpowiednio inne terminy prawnicze niż w przypadku, kiedy translat ma być użyty w Surinamie czy na Curaçao. Podobnie będzie z przekładem na język niemiecki - tłumacz musi wiedzieć, czy krajem przeznaczenia translatu są Niemcy, Austria, Szwajcaria, Liechtenstein, a może Belgia albo Luksemburg. Po drugie, tłumacz nie może ograniczać się w swej pracy do słownika, lecz musi korzystać również z fachowej literatury prawniczej (np. ustawa, komentarz do ustawy). Jest to nieodzowne, ponieważ w odróżnieniu od większości terminów nauk technicznych, terminy prawne nie są uniwersalne, tzn. nie mają swoich odpowiedników w każdym kraju, a jeżeli mają, to wiążą się przeważnie $\mathrm{z}$ różnymi implikacjami - z pojęciami wiążą się bowiem również skutki prawne. 


\section{Podejście terminologiczne w przekładzie tekstów prawniczych}

Koncentrując swą uwagę na porównywaniu terminów prawnych w kontekście przekładu, Sandrini dokonuje adaptacji modelu komparatystyki prawniczej autorstwa rumuńskiego prawoznawcy Constantinesco dla potrzeb komparatystyki terminologicznej. Zgodnie z modelem Constantinesco komparatystyka prawnicza przebiega w trzech etapach (Sandrini 2009: 154-156; 1999b: 105-108): Pierwszym z nich jest "ustalenie" (Feststellen), które polega na przeanalizowaniu definicji pojęć i ustaleniu ich implikacji. Drugim etapem jest "zrozumienie" (Verstehen). Etap ten polega na przeanalizowaniu treści owych pojęć w kontekście systemu konceptualnego danej dziedziny. W oparciu o wyniki dwóch pierwszych etapów w trzecim kroku następuje "porównanie" (Vergleichen) konceptów prawnych przynajmniej dwóch systemów prawnych - w ostatnim kroku chodzi o wskazanie istniejących pomiędzy terminami różnic i podobieństw. Celem "porównania" jest według Sandriniego ustalenie konceptów, które w różnych systemach prawnych dotyczą tego samego aspektu życia społecznego i rozwiązują te same problemy (Sandrini 1999b: 108).

Austriacki językoznawca zauważa, że podejście terminologa jest całościowe i ogólne, tzn. analizuje on koncepty w kontekście całego systemu. Inne z kolei jest podejście thumacza, który dokonuje porównania terminów w kontekście sytuacji, której dotyczy thumaczony tekst. Konsekwencją tego jest dokonane przez Sandriniego rozróżnienie odpowiednio na porównanie systemowe (der systematische Vergleich) i sytuacyjne (der situationsgebundene Vergleich) (Sandrini 2009: 158).

W kontekście komparatystyki terminologicznej Sandrini podkreśla, że całkowita ekwiwalencja pomiędzy pojęciami różnych systemów prawnych nie istnieje, istnieją między nimi jednak związki, których zakres i intensywność można ulokować na trzech poziomach: związek bezpośredni (direct relation, direkte Entsprechung), funkcjonalny (functional relation, indirekte funktionale Entsprechung) i pośredni (indirect relation, erweiterte funktionale Verbindung) (Sandrini 1999b: 109; 1996a: 349; 1996b: 242-246). Związek bezpośredni zachodzi w przypadku pojęć o tej samej intensji i możliwych różnicach ich ekstensji. Druga relacja istnieje w przypadku, kiedy koncepty są 'funkcjonalnie równowartościo- 
we' (funktionale Gleichwertigkeit), tzn. kiedy regulują te same zagadnienia, bądź rozwiązują te same problemy - mają one wówczas pewne wspólne cechy konceptualne. Trzeci rodzaj związku zachodzi pomiędzy pojęciami, które rozwiązują bądź regulują podobne problemy, lecz nie mają wspólnych cech konceptualnych.

Ponieważ na każdym z trzech poziomów istnieje zbieżność terminologiczna odniesiona do funkcji, uważam, iż każdy ze wskazanych zakresów relacji jest w przekładzie wystarczający i umożliwia komunikację interlingualną. Aspekt funkcjonalny jest decydujący w przekładzie tekstów prawniczych również dla Sandriniego i stanowi według niego pomost (functional bridge) pomiędzy terminami odmiennych systemów prawa (Sandrini 1996b: 347).

\section{Rodzaje przekładu w kontekście tekstów prawniczych}

Proces przekładu tekstów prawniczych nie sprowadza się jednak do ustalenia ekwiwalentów funkcjonalnych dla terminów tekstu źródłowego. Pytanie zasadnicze w procesie przekładu brzmi: Jak tłumaczyć?

Według Schleiermachera thumaczyć można na dwa sposoby: albo w sposób wierny (treu), przekazując treść z wszystkimi elementami tekstu źródłowego i pokazując w ten sposób odbiorcy odmienność kultury języka źródłowego, albo w sposób wolny (frei), adaptując niejako tekst źródłowy do reguł i rzeczywistości kraju języka docelowego (Schleiermacher 1813/1973: 47-49). Na bazie tego dwupodziału zwykło się mówić $\mathrm{w}$ teorii translacji odpowiednio o metodzie egzotyzacji (domesticating method) i udomowienia (foreignizing method) w przekładzie (Venuti 1995: 20), o przekładzie jawnym (overt translation) i utajonym (covert translation) (House 2001: 250), o ekwiwalencji formalnej i dynamicznej między tekstem wyjściowym a docelowym (Nida 1964: 159-160) czy o thumaczeniu dosłownym i wolnym (określenia stosowane powszechnie).

Mówiąc o przekładzie dosłownym i wolnym przekładoznawcy kładą nacisk jednak na różne aspekty przekładu. Dla House (2001) kryterium tego dwupodziału stanowi funkcja oraz zasygnalizowanie odbiorcy, że ma on do czynienia z tekstem tłumaczonym (overt translation), bądź zatuszowanie tego faktu (covert translation). Zgodnie z metodą overt 
translation tekst thumaczony jest wiernie i zgodnie z normami obowiązującymi w języku źródłowym. Oznacza to, że takie elementy tekstu źródłowego jak treść, cechy gatunkowe i styl powinny zostać oddane dosłownie i wiernie (House 2001: 250). Jawność przekładu polega bowiem na rozpoznawalności tekstu źródłowego w translacie. Przekład taki nie będzie jednak spełniał w języku docelowym takiej funkcji, jaką oryginał spełnia w języku źródłowym, co wynika zarówno z braku dostosowania translatu do rzeczywistości i do konwencji tekstowo-językowych odbiorcy (House 2001: 250). Odwrotna sytuacja zachodzi w przypadku metody covert translation, zgodnie z którą przekład jest podporządkowany konwencjom obowiązującym w kraju języka docelowego. Zgodnie z tym podejściem takie elementy tekstu źródłowego jak funkcja, cechy gatunkowe, styl i treść są dostosowane do realiów i konwencji odbiorcy.

W przekładzie jawnym (overt), którego celem jest odwzorowanie tekstu źródłowego w języku docelowym, zatracane są jego dwa najważniejsze dla komunikacji elementy: treść i funkcja; podczas gdy w przekładzie utajonym (covert), elementy te są przekazywane. W przekładzie prawniczym przekład utajony (covert translation) wydaje się zatem bardziej odpowiedni. Jego zasadność podważa jednak moim zdaniem dążenie do zatuszowania faktu, iż odbiorca ma do czynienia z przekładem. Odbiorca stosujący translat tekstu prawniczego musi być świadomy, że ma do czynienia $\mathrm{z}$ tekstem obcego systemu prawnego, musi on również wiedzieć, którego kraju prawo to dotyczy. Odmienność systemu prawnego nie powinna być jednak moim zdaniem przez thumacza zaznaczana w sposób, który sprawi, że tekst docelowy będzie wywoływał u odbiorcy wrażenie nienaturalności. Efekt taki mogą wywołać sformułowania, które w języku docelowym nie występują, bądź są postrzegane jako archaiczne. Takie wrażenie może moim zdaniem wywoływać tłumaczenie na język niemiecki nazwy kodeks karny jako Strafkodex. Zupełnie wystarczającym wskazaniem odbiorcy niemieckojęzycznemu na obcy system prawny jest użycie sformułowania języka docelowego z przymiotnikiem utworzonym od nazwy kraju, co w podanym przykładzie da w efekcie polnisches Strafgesetzbuch. Za pomocą przymiotnika sygnalizuje się w podobnych sytuacjach nie tylko przynależność do systemu, lecz również możliwe różnice istniejące pomiędzy pojęciami.

W przekładzie tekstów prawniczych można zatem przyjąć tylko jedno kryterium podejścia covert translation - kryterium funkcji.

Kryterium funkcji stanowi według Nidy o "dynamicznej" relacji pomiędzy tekstem źródłowym a docelowym (Nida 1964: 159). Translat 
o dynamicznej relacji do oryginału powinien oddziaływać na odbiorcę w taki sposób, w jaki tekst źródłowy oddziałuje na odbiorcę pierwotnego (Nida 1964: 159). Przenosząc to na grunt prawa, chodzi zatem o taki rodzaj przekładu, który w kraju języka docelowego wywołuje takie same bądź podobne skutki do tych, jakie oryginał wywołuje w kraju języka docelowego. Rodzaj przekładu, którego celem jest dążenie do uzyskania dynamicznej relacji pomiędzy tekstem źródłowym a docelowym, jest wobec tego, moim zdaniem, właściwy w przekładzie tekstów prawniczych. Wykorzystanie bowiem dokumentów w ramach wykonywanego zawodu (adwokata, prokuratora czy sędziego) podyktowane jest koniecznością działania w oparciu o prawo obcego kraju (np. wykonanie wyroku zagranicznego czy thumaczenie aktu oskarżenia dla osoby oskarżonej za granica). Działanie odbiorcy tekstu docelowego będzie zgodne z intencją nadawcy tekstu źródłowego jedynie w przypadku, kiedy funkcja dokumentu i jego treść będą dla odbiorcy czytelne. Translat, który jest zgodny z tekstem oryginalnym jedynie pod względem formalnym, jak to ma miejsce w przekładzie jawnym, nie przekazuje treści i intencji nadawcy. Za dynamicznym rodzajem przekładu w przypadku tekstów prawniczych przemawia zatem czytelności treści i funkcji tekstu wyjściowego dla odbiorcy translatu.

\section{Lingwistyka tekstu w kontekście przekładu}

Po ustaleniu rodzaju przekładu tekstów prawniczych należy jeszcze rozważyć, jak zamierzony efekt można osiągnąć, tzn. w jaki sposób wykonać przekład o dynamicznej relacji z tekstem źródłowym. Ponieważ proces przekładu jest w moim rozumieniu elementem komunikacji interlingualnej, w której medium stanowi tekst, za zasadne uważam rozważenie tej kwestii w oparciu o lingwistykę tekstu.

Neubert i Shreve (1992) w monografii Translation as Text postulują, by proces przekładu odpowiadał regułom tworzenia tekstu. Autorzy postrzegają tekst jako akt komunikacji, w którym autor jest nadawcą, aczytelnik aktywnym odbiorcą, który czynnie reaguje na komunikat swoim zachowaniem, działaniem czy w sposób werbalny (Neubert i Shreve 1992: 36-37, 39). Tłumacz pełni w takim akcie rolę mediatora, którego zadaniem jest umożliwienie tego rodzaju komunikacji. Zadanie 
to nie polega według wymienionych językoznawców na transformacji językowej, lecz na dostosowaniu komunikatu do realiów i konwencji odbiorcy (Neubert i Shreve 1992: 41). Aby translat mógł być elementem komunikacji wielojęzycznej, musi on, zdaniem Neuberta i Shreve'a, spełniać siedem, wskazanych przez Beaugrande'a i Dresslera, warunków tekstualności, którymi są: intencjonalność, akceptowalność, sytuacjonalność, informatywność, koherencja, kohezja oraz intertekstualność (Neubert i Shreve 1992: 70-123).

Zdaniem Neuberta i Shreve'a translat powinien być zgodny z intencją autora tekstu źródłowego, przy czym intencja ta powinna być czytelna dla odbiorcy tekstu docelowego (Neubert i Shreve 1992: 71-72). Zgodnie z kryterium akceptowalności konwencje tekstowe i styl translatu powinny odpowiadać konwencjom języka docelowego (Neubert i Shreve 1992: 73). Sytuacjonalość polega na uwzględnieniu w przekładzie warunków i sytuacji, w jakich translat ma być recypowany i ewentualnie zastosowany (Neubert i Shreve 1992: 84-88). Jest to zatem kryterium decydujące nie tylko o stylu, lecz również o tym, które treści tekstu źródłowego powinny pojawić się w tekście docelowym, które są niepotrzebna albo niewskazane (Neubert i Shreve 1992: 89). Informatywność translatu dotyczy przekazu treści zgodnie z jej sensem zawartym w tekście źródłowym (Neubert i Shreve 1992: 89). Koherencja to sposób, w jaki informacja (treść) jest w tekście wyrażona (Neubert i Shreve 1992: 95, 98). Dotyczy ona w moim rozumieniu zatem środków semantycznych, za pomocą których informacja jest wyrażana - chodzi tu również np. o sposób jej przedstawienia i argumentacji w tekście. Koherencja jest wobec tego ściśle związana z informatywnością: Kiedy np. Sąd po zapoznaniu się ze sprawą decyduje się skazać oskarżonego na karę pozbawienia wolności, musi informację tą wyrazić w sposób czytelny dla odbiorców (strony procesu, organy wykonujące orzeczenia, sądy wyższej instancji). Wyrok taki musi spełniać pewne wymogi formalne, musi on zostać dobrze uzasadniony, przez opisanie czynu oraz wskazanie przepisów ustawy, którym czyn jest subsumowany. Koherencji odpowiada zatem struktura całego tekstu, której wątkiem jest pewna treść (informacja).

Według Neuberta i Shreve'a koherencję translatu należy skonstruować na nowo w oparciu o strukturę semantyczną tekstu źródłowego; powinna ona jednak być zorientowana na odbiorcę (Neubert i Shreve 1992: 100). Ponieważ odzwierciedleniem koherencji jest struktura tekstu, należy tu według mnie podkreślić, że w przypadku tekstów prawniczych tłumacz nie może zmieniać zasadniczej budowy tekstu. Tłumacząc np. 
obcojęzyczny akt oskarżenia na język polski tłumacz nie może dostosować translatu do formalnych wymogów tego dokumentu określonych w Polsce przez kodeks postępowania karnego (Art. 332-333). Tłumacz może jednak i powinien dokonać pewnych zmian, które sprawią, że treść (informacja) translatu będzie dla odbiorcy bardziej zrozumiała. Możliwą ingerencję zilustruje podany przykład wyroku Trybunału Konstytucyjnego Niemiec:

a) brak ingerencji thumacza na poziomie koherencji:

IM NAMEN DES VOLKES

in dem Verfahren über die Anträge

1. ...

Antragssteller: ...

- Bevollmächtigte: ...

Antragsgegner: ...

- Bevollmächtigte: ...
W IMIENIU NARODU W sprawie dotyczącej wniosków

1. ...

...

Wnioskodawca: ...

- Pełnomocnicy: ...

Strona przeciwna: ...

- Pełnomocnicy: ...

hat das Bundesverfassungsgericht Trybunał Konstytucyjny Niemiec - Zweiter Senat Drugi Senat -

unter Mitwirkung der Richterinnen przy udziale sędzin i sędziów und Richter ...

aufgrund der mündlichen

Verhandlung vom ... durch

\section{Urteil}

für Recht erkannt: na podstawie ustnej rozprawy w dniu ... przez

\section{Wyrok}

postanawia:

b) koherencja translatu zorientowana na odbiorcę:

IM NAMEN DES VOLKES in dem Verfahren über die Anträge

\author{
WYROK \\ W IMIENIU NARODU \\ w sprawie dotyczącej wniosków
}


1. ...

Antragssteller: ...

- Bevollmächtigte: ...

Antragsgegner: ...

- Bevollmächtigte: ...
1. ...

Wnioskodawca: ...

- Pełnomocnicy: ...

Strona przeciwna: ...

- Pełnomocnicy: ...

Trybunał Konstytucyjny Niemiec hat das Bundesverfassungsgericht Drugi Senat - Zweiter Senat -

w składzie: ...

unter Mitwirkung der Richterinnen und Richter ...

po rozpoznaniu na rozprawie ustnej w dniu ...

aufgrund der mündlichen

Verhandlung vom ... durch

orzeka:

\section{Urteil}

für Recht erkannt:

Zasadnicza korekta w drugim przypadku dotyczy nagłówka. Nazwy gatunkowe polskich tekstów specjalistycznych, zwłaszcza prawniczych, tradycyjnie poprzedzają ich treść. Nadawca już na wstępie sygnalizuje w ten sposób odbiorcy, czego informacja dotyczy i wskazuje na rodzaj orzeczenia. Inną kwestią jest obecna w Niemczech poprawność polityczna dotycząca równouprawnienia. W Polsce nie ma jednak tendencji do podkreślania udziału kobiet w dokonywanych czynnościach, wobec czego unter Mitwirkung der Richterinnen und Richter można przetłumaczyć jako $w$ sktadzie - taka też forma występuje w wyrokach polskiego Trybunału Konstytucyjnego. Tłumacząc jednak wyrok polskiego Trybunału Konstytucyjnego na język niemiecki, sformułowanie $w$ składzie powinno zostać przetłumaczone jako unter Mitwirkung der Richterinnen und Richter. Ponieważ w Polsce wszystkie rozprawy odbywają się ustnie, można jeszcze rozważyć, opuszczenie przymiotnika w wyrażeniu po rozpoznaniu na rozprawie ustnej. Decyzja ta zależeć będzie jednak od celu przeznaczenia translatu. 
Podczas gdy koherencja dotyczy sposobu uporządkowania treści w tekście, kohezja dotyczy elementów formalnych wyrażanej treści, tzn. środków językowych (leksykalnych i gramatycznych), za pomocą których treść ta jest wyrażona (Neubert i Shreve 1992: 103). Powracając do podanego wyżej rozróżnienia między informatywnością, a koherencją na przykładzie wyroku: O ile w przypadku koherencji chodziło o namysł nad tym, jak logicznie wyrazić treść wyroku, jak go uzasadnić, jak zbudować cały dokument, to w przypadku kohezji chodzi o rozważenie, jakimi środkami językowymi treść tą wyrazić.

Wierne odtworzenie kohezji leksykalnej tekstu źródłowego w docelowym odpowiada $\mathrm{w}$ moim rozumieniu przekładowi dosłownemu. W translacie takim treść tekstu źródłowego jest jednak najczęściej zatracana. Jeżeli bowiem niemieckie zdanie Sie hat ihm einen Floh ins Ohr gesetzt przetłumaczymy dosłownie ("Włożyła mu pchłę do ucha"), wówczas odbiorca nie dowie się, że tak naprawdę chodzi o sytuację, w której osoba płci żeńskiej zabiła jakiemuś osobnikowi płci męskiej ćwieka, tzn. sprawiła ona, że osobnik zaczął się intensywnie zastanawiać nad rozwiązaniem jakiegoś problemem albo odpowiedzią na jakieś pytanie. Rzecz będzie miała się podobnie, kiedy nazwa niemieckiego sądu pierwszej instancji, Amtsgericht, zostanie przetłumaczona jako "sąd urzędowy". Ponieważ określenie "sąd urzędowy" nie niesie dla polskiego odbiorcy żadnej informacji, powinno się użyć nazwy, którą odbiorca zna, i zaznaczyć przynależność do systemu prawnego za pomocą przymiotnika utworzonego od nazwy kraju, co da w rezultacie Niemiecki Sad Rejonowy. ${ }^{6}$

Również nazwy pozostałych instancji i organów sądowych powinny zostać przetłumaczone w sposób czytelny, czyli pozwalający odbiorcy zrozumieć coś obcego przez analogię do czegoś, co jest mu znane. A zatem thumaczenie nazwy niemieckiego sądu drugiej instancji, Landgericht, powinno brzmieć Niemiecki Sąd Okręgowy, a nie „sąd krajowy”, co może sugerować złożenie niemieckiej nazwy tego sądu (Land - kraj, Gericht - sąd). Bungesgerichtshof z kolei to organ, który w Niemczech pełni taką funkcję jak w Polsce Sąd Najwyższy; jego informatywne i akceptowalne thumaczenie to zatem Niemiecki Sad Najwyższy. Podobnie rzecz się ma z niemieckim organem Bundesverfassungsgericht, któremu

\footnotetext{
$6 \mathrm{~W}$ przypadku tłumaczenia wyroku nie będzie to jednak konieczne, ponieważ w Niemczech, podobnie jak w Polsce, pełna nazwa sądu zawiera informacę o miejscowej właściwości sądu. Określenie Amtsgericht Dresden, przetłumaczymy zatem jako Sąd Rejonowy w Dreźnie.
} 
w Polsce funkcjonalnie odpowiada Trybunał Konstytucyjny. Funkcjonalna ekwiwalencja istniejąca między obu organami przemawia za przethumaczeniem niemieckiej nazwy na język polski jako Niemiecki Trybunat Konstytucyjny. Nie znaczy to jednak, że zawsze powinno się stosować określenia języka docelowego. Ponieważ Polska nie jest federacją, odradzam przetłumaczenie na język niemiecki nazw sądów Sąd Najwyższy oraz Trybunat Konstytucyjny kolejno jako Bundesgerichtshof oraz Bundesverfassungsgericht. W takiej sytuacji za zasadne uważam posłużenie się sformułowaniem definicji terminu będącego ekwiwalentem funkcjonalnym (definiens). Bundesgerichtshof oraz Sąd Najwyższy spełniają w obu krajach bez wątpienia tę samą rolę. Problem stanowi zatem nie funkcja, lecz forma ekwiwalentu, bowiem, jak wspomniałem, Polska nie jest federacją. Słownik prawniczy definiuje Bundesgerichtshof jako der oberste Gerichtshof des Bundes (Creifelds 2017: 261), wobec tego der oberste Gerichtshof Polen( $(s)$ jest według mnie właściwym thumaczeniem nazwy polskiego organu Sąd Najwyższy pod względem funkcjonalnym i formalnym. ${ }^{7}$ Definicja nie zawsze jednak okazuje się pomocna i tak jest np. w przypadku nazwy organu Trybunat Konstytucyjny. Słownik prawniczy definiuje jego niemiecki ekwiwalent funkcjonalny, jakim jest Bundesverfassungsgericht, jako ein allen übrigen Verfassungsorganen gegenüber selbständiger und unabhängiger Gerichtshof des Bundes (Creifelds 2017: 271). Wynikiem zastosowania procedury analogicznej do tej z poprzedniego przykładu byłby przekład Gerichtshof Polen $(s)$. Wadą zasadniczą owego przekładu jest brak zasygnalizowania odbiorcy niemieckojęzycznemu, że jest to sąd konstytucyjny. Verfassungsgerichtshof Polen $(s)$ jest w tej sytuacji rozwiązaniem możliwym i z pewnością dla odbiorcy niemieckojęzycznego czytelnym, zresztą nazwa organu, o którym mowa brzmi w Austrii właśnie Verfassungsgerichtshof Österreich. Zakładając jednak, że tekst tłumaczony jest dla odbiorcy niemieckiego, a nie austriackiego można znaleźć jeszcze inne rozwiązanie. ${ }^{8}$

Proponuję w tym celu skoncentrować się na formie określenia (definiendum). Bundesverfassungsgericht to złożenie składające się $\mathrm{z}$ trzech leksemów: Bund (federacja/związek), Verfassung (konstytucja) oraz Gericht (sąd). Bundesverfassungsgericht to zatem sąd konstytucyjny

\footnotetext{
7 Uważam, że thumaczenie das oberste Gericht jest dla odbiorcy niemieckojęzycznego nieznacznie mniej informatywne.

8 Podkreślam jednak, że Verfassungsgerichtshof Polen( $(s)$ jest thumaczeniem, które w sposób wystarczający i poprawny informuje odbiorcę tak austriackiego jak niemieckiego o tym, że mowa jest o polskim Trybunale Konstytucyjnym.
} 
federacji, domyślnie Niemiec ${ }^{9}$, co można wyrazić po niemiecku również jako Verfassungsgericht des Bundes, albo Verfassungsgericht Deutschland(s). ${ }^{10}$ Ponieważ złożenie Verfassungsgericht oznacza dla odbiorcy w Niemczech sad konstytucyjny, wobec tego Verfassungsgericht Polen( $(s)$ jest według mnie thumaczeniem nieznacznie lepszym od Verfassungsgerichtshof Polen $(s)$.

Powracając do kryteriów tekstualności: Kohezja gramatyczna dotyczy w kontekście przekładu preferencji środków gramatycznych (m.in. czasów, trybów i strony czasownika). Mając na uwadze zasadę akceptowalności oraz kryterium informatywności, uważam, że koherencja gramatyczna powinna być zgodna z konwencjami obowiązującym w kraju języka docelowego. ${ }^{11}$ Tłumacz powinien zatem znać nie tylko cały arsenał środków gramatycznych języka docelowego, powinien on również wiedzieć, jakie środki gramatyczne (m.in. czasy, tryby i strony czasownika) są charakterystyczne dla danego gatunku tekstu. A zatem np. w thumaczeniu hiszpańskojęzycznego tekstu specjalistycznego na język niemiecki tłumacz nie powinien zapominać o używaniu strony biernej, której częstotliwość użycia jest w niemieckich tekstach specjalistycznych porównywalnie dużo większa (Reinart i Pöckl 2015: 58).

Ostatnim, siódmym, elementem tekstualności, jest intertekstualność. Neubert i Shreve definiują intertekstualność w kontekście przekładu jako relację między translatem, a innymi tekstami należącymi w języku docelowym do tego samego gatunku. Autorzy Translation as Text są skłonni uznać intertekstualność za najważniejszy dla tłumacza aspekt tekstualności, ponieważ decyzje związane z intencjonalnością, akceptowalnością, sytuacjonalnością, informatywnością, koherencją i kohezją powinien on podejmować w oparciu o konwencje gatunkowe, obowiązujące w kraju języka docelowego (Neubert i Shreve 1992: 118).

W tym kontekście warto zastanowić się nad aspektem celowości W przekładzie tekstów prawniczych, czyli nad skoposem. W kontekście

9 Austria również jest związkiem, lecz nazwa tamtejszego trybunału brzmi der Österreichische Verfassungsgerichtshof, ewentualnie Verfassungsgerichtshof Österreich. W Szwajcarii z kolei nie ma Trybunału Konstytucyjnego.

10 Dopełniacz nie jest konieczny, czego dowodem jest austriacka nazwa własna tego organu.

11Konwencje dotyczące środków gramatycznych można określić na podstawie badań ilościowych. Szubert (2008) ustalił w ten sposób preferencje dotyczące kategorii gramatycznych czasownika w wybranych gatunkach tekstów prawa polskiego i niemieckiego.

108 
przekładu tekstów prawniczych opinie na temat teorii skoposu, której autorami są niemieccy językoznawcy Reiß i Vermeer (1984) są różne. Sandrini jest zwolennikiem wspomnianej teorii i uważa, że w przekładzie prawniczym skopos odgrywa rolę decydującą (Sandrini 2009: 44). Według Šarčević teorię skoposu można zastosować w przekładzie tekstów prawniczych tylko w odniesieniu do niektórych aspektów: Styl i formę można według niej tłumaczyć na różne sposoby, natomiast funkcja translatu nie powinna różnić się od funkcji tekstu oryginalnego (Šarčević 1997: 18). W innym miejscu stwierdza ona bardziej stanowczo, że „teksty prawa podlegają przepisom prawnym, które decydują o sposobie ich użytkowania w procedurze prawnej" ${ }^{12}$ (Šarčević 2000: 2). Simonnæs z kolei jest zdania, że sposób tłumaczenia tekstu prawniczego zależy od statusu tekstu, tzn. od tego, czy ma on charakter normatywny, czy informatywny. W przypadku tekstów informatywnych dopuszczalna jest jej zdaniem większa swoboda i dowolność przekładu, natomiast w przypadku tekstów normatywnych translat powinien spełniać taką samą funkcję, jaką pełni oryginał, tzn. powinien on wywoływać taki sam efekt w kraju języka docelowego, jaki tekst oryginalny wywołuje w kraju języka wyjściowego - tylko w takim wypadku można jej zdaniem mówić o "ekwiwalencji prawnej" (legal equivalence) (Simonnæs 2013: 150).

Poglądy Šarčević i Simonnæs dotyczące teorii skoposu nie są sprzeczne. Stwierdzenie, że 'sposób użytkowania tekstów prawniczych regulowany jest przez procedurę prawną' (Šarčević 1997: 18), oznacza w moim rozumieniu, że każdy gatunek tekstu z zakresu prawa jest używany w określonych sytuacjach i dla określonych celów. Przepisy prawne, które te kwestie regulują dotyczą jednak tekstów prawniczych używanych przez prawników w czynnościach prawa stosowanego, a nie teoretycznego. Dlatego też Simonnæs słusznie moim zdaniem zauważa, że większa swoboda istnieje w przypadku przekładu informatywnych tekstów prawniczych (np. podręcznik dla studentów prawa, artykuł naukowy). Swoboda ta nie jest jednak według mnie nieograniczona. Sposób użycia i przekładu prawniczych tekstów informatywnych są bowiem regulowane przez konwencje gatunkowe, o czym stanowi kryterium intertekstualności.

12 Tłumaczenie własne: „legal texts are subject to legal rules governing their usage in the mechanism of the law". 
Uwzględnienie aspektów tekstualności w przekładzie tekstów prawniczych, oraz tekstów każdej innej dziedziny, jest według mnie niezbywalne. Przekład specjalistyczny nie ogranicza się do ustalenia ekwiwalencji na poziomie terminologicznym, ponieważ tekst specjalistyczny nie składa się jedynie z terminów. Stosowanie się do konwencji gatunkowych języka docelowego, czyli przekład zorientowany na odbiorcę, daje tłumaczowi z kolei szansę osiągnąć ekwiwalencję dynamiczną pomiędzy tekstem źródłowym a docelowym, co w efekcie pozwala translatowi pełnić rolę medium komunikacji interlingualnej. Warunkiem komunikacji jest bowiem zrozumienie informacji komunikatu zgodnie z intencjami nadawcy.

\section{Podsumowanie}

Na podstawie powyższych rozważań można wyciągnąć następujące wnioski:

Po pierwsze, każdy system prawny jest unikalny i ściśle związany z realiami kraju, w którym obowiązuje. Znaczy to, że w każdym kraju istnieją zasadnicze różnice dotyczące regulowania życia społecznego i rozwiązywania problemów za pomocą prawa. Różnice konceptualnych systemów prawnych implikują z kolei różnice na poziomie terminologicznym.

Po drugie, różnice wynikające z kulturowego uwarunkowania prawa można ustalić za pomocą komparatystyki prawniczo-terminologicznej, która jest połączeniem elementów komparatystyki prawniczej oraz terminologicznej. Celem takiej komparatystyki jest ustalenie ekwiwalentów funkcjonalnych dla terminów tłumaczonego tekstu.

Po trzecie, po ustaleniu ekwiwalentów funkcjonalnych terminów występujących $\mathrm{w}$ thumaczonym tekście, uwaga kierowana jest na elementy gatunkowe tłumaczonego tekstu. W przekładzie tekstów prawniczych ważną rolę odgrywa analiza cech gatunkowych tekstów paralelnych, tj. takich, które kraju języka docelowego pełnią taką samą rolę, jak tekst oryginalny w kraju języka źródłowego. Przekład powinien uwzględniać konwencje gatunkowe kraju języka docelowego. Tłumacz nie może przy tym jednak dostosowywać translatu do formalnych wymogów kraju języka docelowego, zmieniając w ten sposób treść oryginału. 
Z powyższego wynika, iż analiza kontrastywna jest niezbywalnym elementem procesu przekładu tekstów prawniczych, tak na poziomie mikro (termin) jak i makro (tekst).

\section{Bibliografia}

Arntz, Reiner. 1999. Rechtsvergleichung und kontrastive Terminologiearbeit: Möglichkeiten und Grenzen interdisziplinären Arbeitens. W Übersetzen von Rechtstexten, red. Sandrini, Peter, 185201. Tübingen: Narr.

Bourdieu, Pierre. 1987. The Force of Law: Toward a Sociology of the Juridical Field. W The Hastings Law Journal 38, 805-853.

Creifelds Rechtswörterbuch. 2017. München: Beck.

Groot, Gerard-René de. 1985. Probleme juristischer Übersetzungen aus der Perspektive eines Rechtsvergleichers. W (Japanese) Comparative Law Reviev XIX-3, 1-45.

Groot, Gerard-René de. 1990. Die relative Äquivalenz juristischer Begriffe und deren Folge für mehrsprachige juristische Wörterbücher. W Translation and Meaning, Part I, red. Thelen Marcel, i Barbara Lewandowska-Tomaszczyk, 122-128. Maastricht: Euroterm.

Groot, Gérard-René de. 1991. Recht, Rechtssprache und RechtssystemBetrachtungen über die Problematik der Übersetzung juristischer Texte. W Terminologie et Traduction 3, 279-316.

Groot, Gérard-René de. 1999. Das Übersetzen juristischer Terminologie. W Recht und Übersetzen, red. Groot, Gérard-René de, i Reiner Schulze, 11-46. Baden-Baden: Nomos.

Grossi, Paolo. 2010. A history of European law. Tłum. Laurence Hooper. Chichester: Blackwell.

House, Juliane. 2001. Translation quality assessment: Linguistic description versus social evaluation. W

Meta: Journal des traducteurs 46 (2), 243-257.

Mayer, Max Ernst. 1933. Rechtsphilosophie. Berlin: Springer.

Mezey, Naomi. 2001. Law as culture. W The Yale Journal of Law \& the Humanities 13, 35-67. 
Neubert, Albrecht, i Gregory M. Shreve, 1992. Translation as text. Kent: The Kent State University Press.

Olpińska, Magdalena. 2009. Polski i niemiecki język specjalistyczny prawa - możliwości i ograniczenia dydaktyki tlumaczenia tekstów specjalistycznych. W Komunikacja specjalistyczna 2, 79-92.

Otto, Walter. 1981. Die Paradoxie der Fachsprache. W Die Sprache des Rechts und der Verwaltung II: Der öffentliche Sprachgebrauch. 44-57. Stuttgart: Klett-Cotta.

Nida, Eugene A. 1964. Toward a Science of Translating. With Special Reference to Principles and Procedures Involved in Bible Translating. Leiden: Brill.

Raz, Joseph. 2009. Between Authority and Interpretation. On the Theory of Law and Practical Reason. New York: Oxford University Press.

Reinart, Sylvia, i Wolfgang Pöckl. 2015. Romanische Fachsprachen. Eine Einführung mit Perspektiven aus der Übersetzungswissenschaft. Berlin: de Gruyter.

Reiß, Katharina, i Hans J. Vermeer. 1984. Grundlegung einer allgemeinen Translationstheorie. Tübingen: Niemeyer.

Sandrini, Peter. 1996a. Terminologiearbeit im Recht: deskriptiver begriffsorientierter Ansatz vom Standpunkt des Übersetzers. Vienna: TermNet.

Sandrini, Peter. 1996b. Comparative analysis of legal terms: Equivalence revisited. W TKE '96: Terminology and Knowledge Engineering. Proceedings of the 4th International Congress on Terminology and Knowledge Engineering, Wien 26.-28. August 1996, red. Galinski, Christian, i Klaus D. Schmitz, 342-350. Frankfurt: Indeks.

Sandrini, Peter. 1998a. Übersetzung von Rechtstexten: Die Rechtsordnung als Kommunikationsrahmen. W LSP Identity and Interface. Research, Knowledge and Society, 865-876. Kopenhagen: Copenhagen Business School.

Sandrini, Peter. 1998b. Terminographie und Textographie: Synergien und Parallelen. W Text, Sprache, Kultur. Festschrift zum 50jährigen Bestehen des Institutes für Übersetzer- und Dolmetscherausbildung der Universität Innsbruck, red. Holzer, Peter, i Cornelia Feyrer, 185-201. Wien: Peter Lang.

Sandrini, Peter. 1999a. Translation zwischen Kultur und Kommunikation: Der Sonderfall Recht. W Übersetzen von Rechtstexten. 
Fachkommunikation im Spannungsfeld zwischen Rechtsordnung und Sprache, 9-43. Tübingen: Narr.

Sandrini, Peter. 1999b. Legal terminology. Some Aspects for a New Methodology. W Hermes: Journal of Linguistics 22, 101-111.

Sandrini, Peter. 2009. Der transkulturelle Vergleich von Rechtsbegriffen. W Legal Language in Action: Translation, Terminology, Drafting and Procedural Issues, red. Šarčevič, Susan, 151-165. Zagreb: Globus.

Šarčevič, Susan. 1997. New approach to legal translation. The Hague: Kluwer Law International.

Šarčevič, Susan. 2000. Legal Translation and Translation Theory: a Receiver-oriented Approach. http://www.tradulex.com/Actes2000/sarcevic.pdf.

Schleiermacher, Friedrich. 1973. Über die verschiedenen Methoden des Übersetzens. W Das Problem des Übersetzens, red. Störig, Joachim S., 38-69. Darmstadt: Wissenschaftliche Buchgesellschaft.

Simonnæs, Ingrid. 2013. Legal translation and "traditional" comparative law-Similarities and differences. W Linguistica Antverpiensia: New Series - Themes in Translation Studies 12, 147-160.

Szubert, Rafał. 2008. Deutsch-polnische kontrastive Untersuchungen im Bereich der juristuschen Fachsprache. Dresden-Wrocław: Neisse Verlag.

Venuti, Lawrence. 1995. The Translator's Invisibility. A history of Translation. London: Taylor \& Francis.

Wróblewski, Bronisław. 1948. Język prawny i prawniczy, Kraków: PAU. Zweigert, Konrad, i Hein Kötz. 1996. Einführung in die Rechtsvergleichung auf dem Gebiete des Privatrechts. Tübingen: Mohr Siebeck.

Teksty normatywne:

Ustawa z dnia 17 listopada 1964 r. - Kodeks postępowania cywilnego.

Ustawa z dnia 6 czerwca 1997 r. - Kodeks postępowania karnego.

Ustawa z dnia 6 czerwca 1997 r. - Kodeks karny.

Ustawa z dnia 14 lutergo 1991 r. - Prawo o notariacie.

Ustawa z dnia 4 lutego 2011 r. - Prawo prywatne międzynarodowe. 